\title{
酸化物系超電導薄膜形成用ターゲット材
}

\author{
格原忠大内幸弘 ${ }^{2}$ 武下拓夫
}

1. は じめに

BednorzとMüller ${ }^{1)}$ にりり発見された $\mathrm{La}-\mathrm{Ba}-\mathrm{Cu}-\mathrm{O}$ 系酸化 物が, 従来の金属系超電導体 $\left(\mathrm{Nb}_{3} \mathrm{Sn}\right)$ の遷移温度 $\left(T_{c}=23.2 \mathrm{~K}\right)$ をはるかに超える超電導体であることが確認されて以来, 酸化物 が超電導体の主役として登場してきた。1987年 2 月に, Toが液体 窒素温度を超光る90K級の $\mathrm{Y}-\mathrm{Ba}-\mathrm{Cu}-\mathrm{O}$ 系 $(\mathrm{YBCO})$ が $\mathrm{Chu}{ }^{2)}$ により合成され，さらに希土類元素を含まずしかも $T_{c}$ が $100 \mathrm{~K}$ を超 える Bi - $\mathrm{Sr}-\mathrm{Ca}-\mathrm{Cu}-\mathrm{O}$ 系 $(\mathrm{BSCCO})$ が金材研の前田ら ${ }^{3)}$ によ りまた Tl-Ba-Cu-O系 $(\mathrm{TBCCO})$ がHermann $5^{4)}$ に合成され るにおよんでこれら酸化物系超電導体は学問的な興味のみならず 実際的な応用の面から多大な注目を集めている。

三荾金属においても，酸化物超電道体の大きなポテンシャルに 注目し, 実用上重要な要素技術である線材化, 薄膜化の研究を, 昨年初頭より行なってきている。薄膜化技術には種々の手法があ るが後述するようにスパッタリング法は多くの利点があるので, スパッタリング法による成膜技術も研究している。この研究には, 良質のターゲット材は必須であるので，当社の従来から蓄積され た技術を駆使して酸化物超電導薄膜用ターゲット材の開発をまず 行ない，良質の薄膜製造が行なえる目処もたったので, ユーザの 要望に応えるためスパッタリング用ターゲットの外販を行なって 好評を得ている。ここでは当社のスパッタリング用ターゲット材 の製造法と成膜技術につき概説する。図 1には, 当社の Y B C O 系ターゲットを示してあるが, これは1987年, 日経産業賞を受賞 したものである。

\section{2. ターゲット材について}

酸化物系薄膜の作製法としては, (反応性) 蒸着法, CVD法, ス パッタリング法等 ${ }^{5)}$ が主として採用されているが，スハッッリン グ法は，(1)高融点物質でも蒸発が可能，(2)多成分系物質の成膜が 容易で蒸発源（ターゲット材）と付着膜との組成ずれが少ない, (3)蒸発粒子が比較的高いエネルギーを有するため基板表面での運

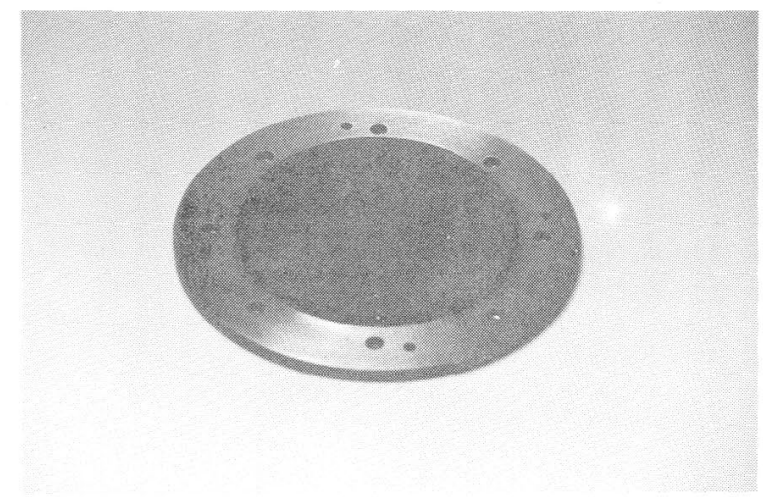

図1Y Y B O 系ターゲット

1. 理博 三菱金属 (侏) 中央研究所超電材プロシェクト

2. 三菱金属 (株) 中央研究所超電材プロジェクト

3. $\mathrm{Ph}$. D。 三菱金属 (株) 中央研究所超電材プロジェクトリーダー
動の活性化が高くエピタキシャル成長が可能である，という利点 を有している。スパッタリング法のこのような利点 ${ }^{6)}$ を利用して， 酸化物系超電導薄膜の製造にはスパッタリング成膜法が最も多く 用いられている。

スパッタリング法による成膜では, ターゲット材と呼ばれる原 料蒸発源が必要であり, 良質な超電導薄膜を製造するためにター ゲット材の品質, 特性が 1 つの重要な因子となっている。ターゲ ット材に要求される特性の主たる点として, (1)高純度で, 超電導 特性を劣化させる不純物を含まないこと, (2)スパッタリング中に 付着膜の組成ずれが生じないよう均質かつ微細な組織であること， (3) 八イパワーによる高速成膜に耐えられるよう糹密で, 使用中に クラックのようなものが発生しないこと, 等が要求される。本文 においては，具体例とともに上記特性を満足するターゲット材の 製造法の技術的なキーポイントに重点をおいて述べる。

\section{3.ターゲット材製造プロセス}

YBCO系の製造工程フローチャートを図2に，BSCCO系のフ ローチャートを図ろに示す。共に固相反応粉をホットブレス用原 料粉として用いる場合を例としている。この方法は, 研究室規模 で粉あるいは焼結体を作成する方法と基本的に同じであるが, 10 $\mathrm{kg} /$ / ッチの粉を扱っているので, 粉を多量に扱うという点で工 夫が必要である。製造工程中, 最も重要な 2 工程, すなわち焼結

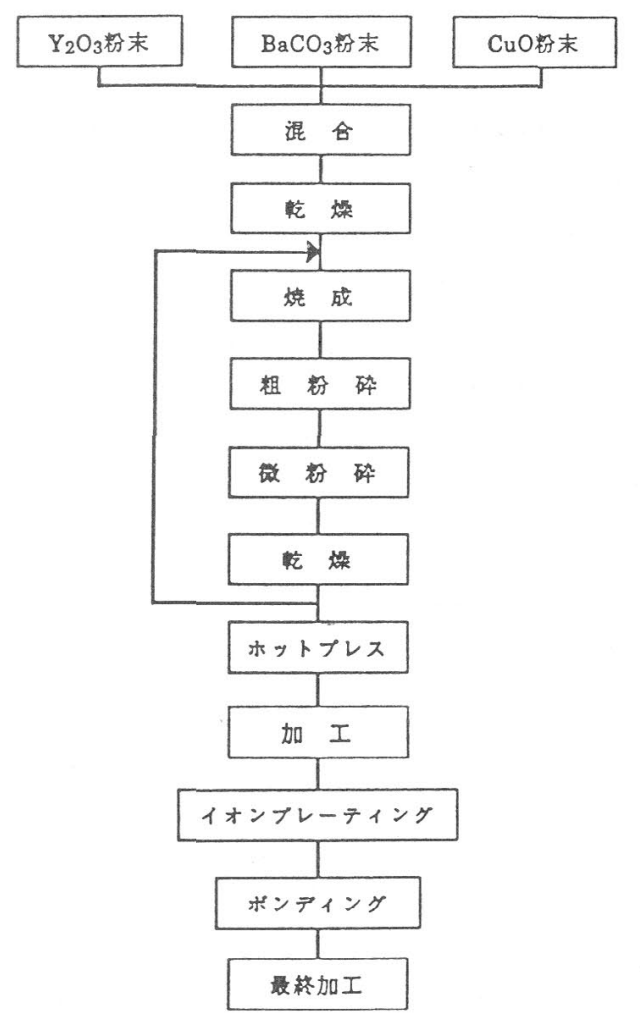

図2 Y B CO系ターゲット村製造プロセスフローチャート

105 (1989) No.2 


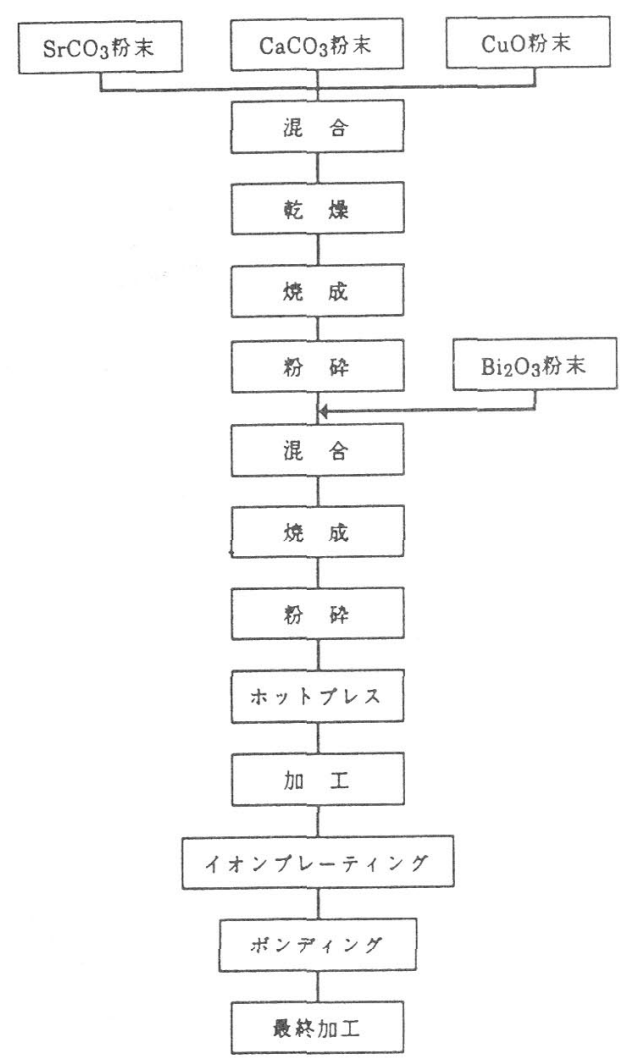

図3 B S C C O 系ターゲット材製造プロセスフローチャート 用原料粉製造工程と焼結体製造工程につき詳しく述べる。

\section{$3 \cdot 1$ 焼結用原料粉の製造}

焼結に用いる原料粉の製造法は大別すると固相反応法之共沈粉 熱分解法 (以後, 共沈法之略称) に分けられる ${ }^{7)} \mathrm{YBCO}$ 系の固 相反応粉は図 2 に示したように出発原料として 3 N 以上の純度を 有しかつ粒径が揃った $\mathrm{Y}_{2} \mathrm{O}_{3}, \mathrm{BaCO}_{3}, \mathrm{CuO}$ 粉末を用いる。混合組 成は定比組成いわゆる $(1-2-3)$ 組成より $\mathrm{CuO}$ 過剩, あるいは $\mathrm{BaCO}_{3}$ と $\mathrm{CuO}$ ともに過剩である場合が多い。反応温度は 890 C $\mathrm{C} / 10$

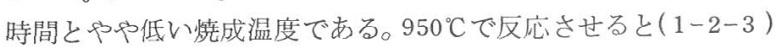
相は比較的容易に生成するが，反応粉の暁結が進み，適当な粒度 に粉砕するのが困難になる。焼成時, 混合粉をプレスしペレット 状成形物の作製は行なわないので，完全に反応させるため酸素ガ 又気流中で $2 \sim 3$ 回焼成をくり返す必要がある。最終的にボール ミルにより平均粒径 4 $5 \mu \mathrm{m}$ まで粉砕し焼結用原料粉とする。 原料粉は焼結工程前にX線回折法により相の分析を行なう。有害 不純物(相)としては未反応 $\mathrm{BaCO}_{3}$ であり，数重量\%が残留しても 焼結特性に著しい悪影響を及济す。

BSCCO 系の固相反応粉製造工程は図 3 に示したが, YBCO系 と同様に, $3 \mathrm{~N}$ レベル以上の純度で粒佳の揃った $\mathrm{Bi}_{2} \mathrm{O}_{3}, \mathrm{SrCO}_{3}$, $\mathrm{CaCO}_{3}, \mathrm{CuO}$ 出発原料粉として用いることが重要である。 $\mathrm{YBC}$ $\mathrm{O}$ 系の製造工程と異なる点は, あらかじめ $\mathrm{Sr}-\mathrm{Ca}-\mathrm{Cu}-\mathrm{O}$ 系酸化 物を合成し, 後で $\mathrm{Bi}_{2} \mathrm{O}_{3}$ 粉を加えて焼成し $\mathrm{BSCCO}$ 系焼結用原料 粉を製造する点である。この方法の利点は, $\mathrm{Sr}-\mathrm{Ca}-\mathrm{Cu}-\mathrm{O}$ 系酸 化物の合成時に, 焼成温度を $900 \sim 1000{ }^{\circ} \mathrm{C}$ と高く設定することが 可能で, 反応粉中の残留 $\mathrm{CO}_{3}$ 基を含む不純物量を容易に減少させ, 焼結性を高めることができる点にある。ボールミル粉䂗粉の平均 粒径は 4 $5 \mu \mathrm{m}$ と管理されている。

$\mathrm{T} 1-\mathrm{Ba}-\mathrm{Ca}-\mathrm{Cu}-\mathrm{O}$ 系の焼結用原料粉の製造法は, BSCCO 系 とほぼ同様で, $\mathrm{Ba}-\mathrm{Ca}-\mathrm{Cu}-\mathrm{O}$ 系酸化物に $\mathrm{Tl}_{2} \mathrm{O}_{3}$ 粉を加光反応さ せている。T1成分の蒸発を防ぐため石英ガラス中で, 焼成温度を

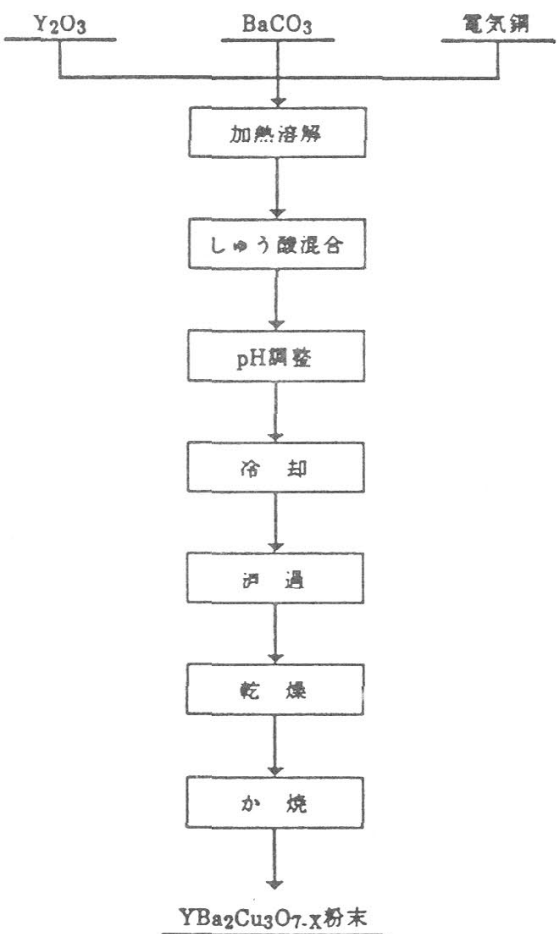

図4 しゅう酸塩共沈粉製造フローチャート（ $\mathrm{YBCO})$ 600〜 $700{ }^{\circ} \mathrm{C}$ と低くしているため生産性が悪い。

焼結用原料粉の製造法として共沈法 ${ }^{7)}$ も採用している。共沈法 には沈殿を作る際に用いる酸の種類により，しゅう酸塩法，炭酸 塩法, クェン酸塩法があるが, $10 \mathrm{~kg} /$ バッチ程度の工程ではコス 卜的にしゅう酸塩法が有利である。しゅう酸塩法のフローチャー 卜をYBCO系を例として図4に示す。沈殿物は無定形であるが,

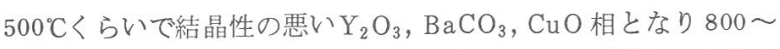
$900{ }^{\circ} \mathrm{C} て ゙(1-2-3)$ 相が生成する。共沈法ではより低温で, より少 ない焼成回数（1２回）で反応粉が得られるのが特長である。 $900{ }^{\circ} \mathrm{C}$ で焼成した共沈法粉末のS EM 写真を図5に示す。平均粒径 2 3 $\mu \mathrm{m}$ で粒径の良く揃った粉末である。ターゲット材として定 比組成 ( $\mathrm{Y}_{1.0} \mathrm{Ba}_{2.0} \mathrm{Cu}_{3.0} \mathrm{O}_{\mathrm{x}}, \mathrm{Bi}_{2.0} \mathrm{Sr}_{2.0} \mathrm{Ca}_{2.0} \mathrm{Cu}_{3.0} \mathrm{O}_{\mathrm{y}}$ 等 $)$ であるこ とは少ないので，あらかじめ定比組成の共沈粉末を多量に作製し ておき,後で $\mathrm{Bi}_{2} \mathrm{O}_{3}, \mathrm{CuO}$ 粉等を混合し所定の組成を持つ焼結用 原料粉を製造する。

\section{$3 \cdot 2$ 焼結プロセス}

ターゲット材製造プロセスの中心工程であり大型品焼結技術の 粋を集めている。一般的に, 粉末の焼結には常圧焼結法, ホット

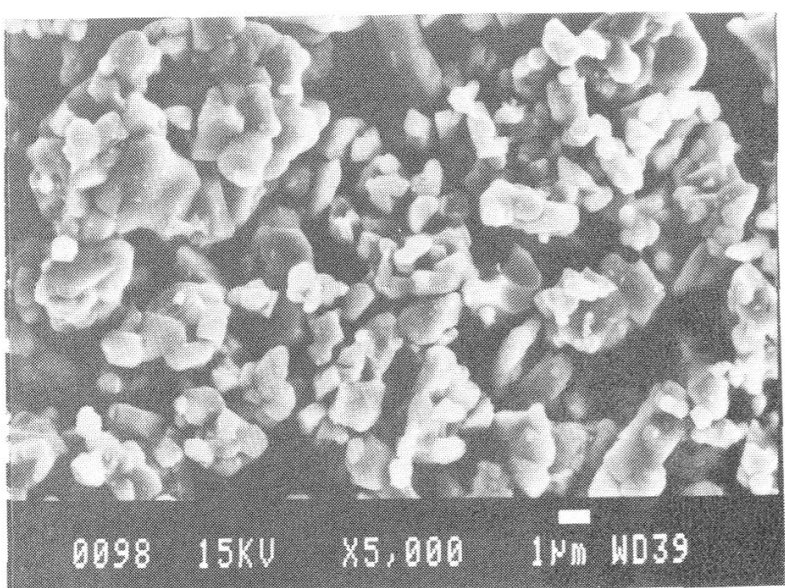

図 5 共沈法で得た $(1-2-3)$ 組成粉末の SEM写真 (YBCO) 


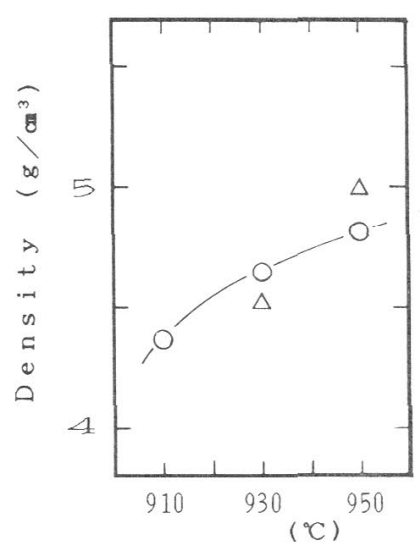

Sintering Temperature

- $\bigcirc$ - 固相反応粉 $-\triangle$ - 共沈粉

図 6 焼結体密度已燒結温度 ( $\mathrm{Y}^{\prime} \mathrm{B}$ C O 系)

プレス焼結法, 熱間静水压焼結 (HIP)法,あるいは反応焼結法が 用いられ，それぞれ特長があり材料，形状，用途により最も適し た焼結方法により材料の性質を十分に発揮できるよう工夫がなさ れる。拝そらく研究室レベルでは, 酸化物系超電導体の烧結には 常圧焼結法が多用されているであ万う。この方法はきわめて簡便 で, 焼結用原料粉末を金型でプレス成形後, 高温で焼結する。図 6に常圧焼結法でのYBCO系焼結体密度と焼結温度の関係を示す。 ボールミル粉砕 (平均粒径 $4 \mu \mathrm{m}$ ) 後, $3 \mathrm{t} / \mathrm{cm}^{2}$ で予備成形した 成形体を $9500^{\circ} \mathrm{C}$ で焼結すると密度 $4.8 \mathrm{~g} / \mathrm{cm}^{3}$ の焼結体が得られた。 固相反応粉と共沈粉では燒結体密度にあまり差はない。これは, 焼結用原料粉の粒径がほぼ同じためである。

B SCCO系粉未の常圧焼結には大きな問題がある。 $\mathrm{Bi}_{2} \mathrm{Sr}_{2}$ $\mathrm{Ca}_{2} \mathrm{Cu}_{3} \mathrm{O}_{10}$ ( いわゆる2223) 相の融点は〜 $890^{\circ} \mathrm{C}^{8)}$ であるが〜 $840{ }^{\circ} \mathrm{C}$ 以上の温度で部分溶融的に鱗片状結晶が成長するとともに 焼結体が膨張するため高い温度での緻密化が難しい。800Cでの常 王焼結体密度は $4.5 \mathrm{~g} / \mathrm{c} \mathrm{m}^{3}$ 程度 ( 理論密度 $6.35 \mathrm{~g} / \mathrm{cm}^{3}$ ) であり高 密度焼結体とは言いがたい。

常圧焼結法は, 焼結の駆動力が主として昖散によるため, 焼結 には高い温度か, 長時間が必要となる。図7 はY $\mathrm{YCO}$ 系 $950^{\circ} \mathrm{C} / 17$ 時間焼結体組織である。緻密化とともに粒成長し組織の微細性が 失なわれるとともに, ターゲット材として所定の形状に加工する ことが難しくなる。微細な組織を保つために, 低温で常圧焼結す ると空孔量の多い焼結体となり, ターゲット冷却のために裹打ち されている銅製バッキングプレートとの接合が難しくなる。冷却 不良はスパッタリング中の付着膜組成变動をひきおこす。

緻密度を向上させることが容易で，粒成長をともなおないホッ

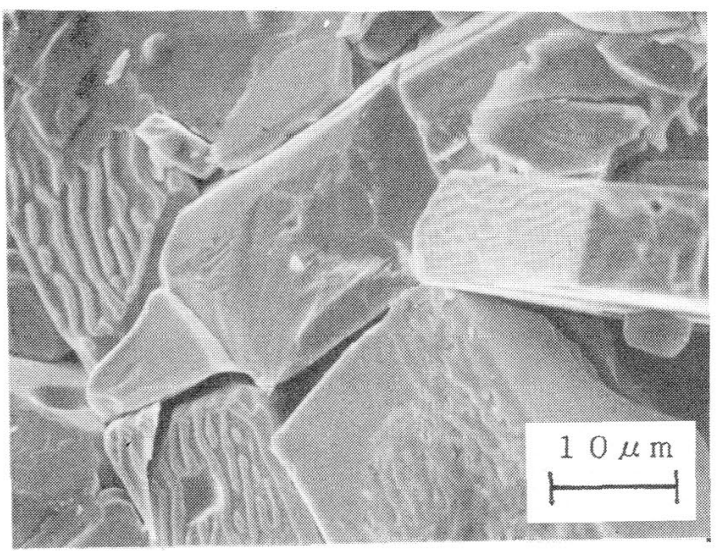

図 7 Y B C O 焼結体組織

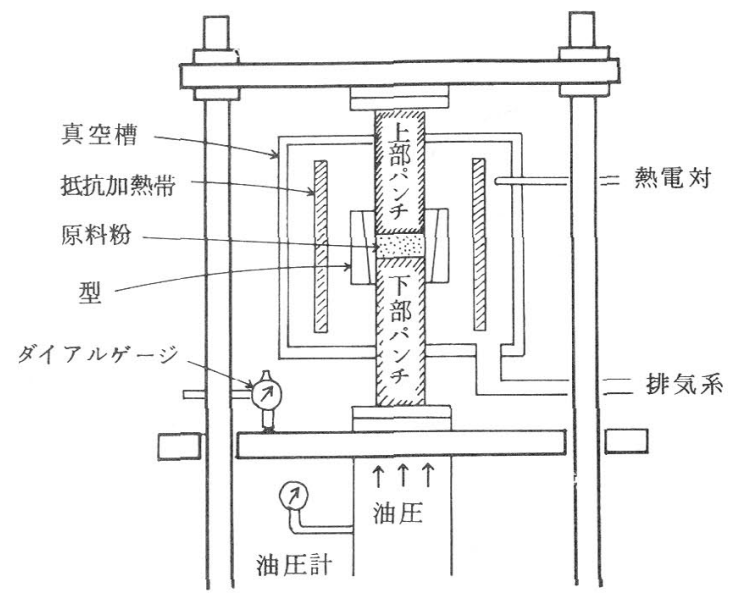

図8ホットプレス概略図

トプレス焼結法は,ターゲット材にとって理想的な焼結法といえ る。図8に抵抗加熱式のホットプレス炉の一例を示す。ホットプ レス法は原料粉末を黒鉛製モールドに入れ，抵抗加熱あるいは誘 導加熱により，モールドを加熱すると同時に一軸方向に加圧し焼 結の駆動力として拡散にプラスして外圧による塑性流動を付加し， 比較的低温域で短時間に焼結する方法である。このため粒成長が 抑えられ微細組織で緻密な焼結体が製造できる。

平均粒径 $5 \mu \mathrm{m}$ の $(1-2-3)$ 組成 $\mathrm{YBCO}$ 原料粉考具体例とし て述べよう。原料粉末を黒鉛モールドに充填し室温より〜 $200 \mathrm{~kg}$ $/ \mathrm{cm}^{2}$ の圧力を負荷した状態で $850^{\circ} \mathrm{C}$ まで昇温し，3 時間保持する。 昇温中 $700^{\circ} \mathrm{C}$ 付近で緻密化が始まり, $800^{\circ} \mathrm{C}$ 付近で著しく緻密化す る。焼結体は黒鉛モールドとの型離れは良いが試料表面に赤かっ 色の変質層が見られる。黒鉛製モールドの影響により $(1-2-3)$ 相が分解し, $\mathrm{Cu}_{2} \mathrm{O} . \mathrm{BaCuO}_{2}, \mathrm{Y}_{2} \mathrm{BaCuO}_{5}$ 相が生成したものと考允ら れる。この表面変質層は $0.1 \mathrm{~mm}$ 程度で取り除くことは容易である。 $850{ }^{\circ} \mathrm{C}$ でのホットプレス焼結体は正方晶系で格子定数 $a=3.86 \AA$, $c=11.78 \AA, \mathrm{Y}, \mathrm{Ba}, \mathrm{Cu}$ は, ICP法によりまたOは熱分析により 定量され, 組成泼 $\mathrm{Y}_{1.0} \mathrm{Ba} \mathrm{B}_{2.0} \mathrm{Cu}_{3.0} \mathrm{O}_{6.3}$ と推定した。焼結密度は 5.60 $\mathrm{g} / \mathrm{cm}^{3}$ であり, 正方晶の理論密度 $6.12 \mathrm{~g} / \mathrm{cm}^{3}$ より相対密度 $90 \%$ を 越えている。ホットプレス焼結体の代表的な組織写真を図9に示 す。わずかに空孔は認められるが構成粒子径は，抒およそ5 $\mu \mathrm{m}$ と原料粉末の粒径と同じで，ホットプレス焼結中に粒成長は生じ ていないことが明らかである。共沈粉でもほぼ同様の密度を持つ 焼結体が得られる。

ホットプレス焼結体の超電導特性を調べるため, 酸素雾曲気中 でアニール試験を行なった。図10,11はをれぞれ $600^{\circ} \mathrm{C}, 950^{\circ} \mathrm{C}$ ア

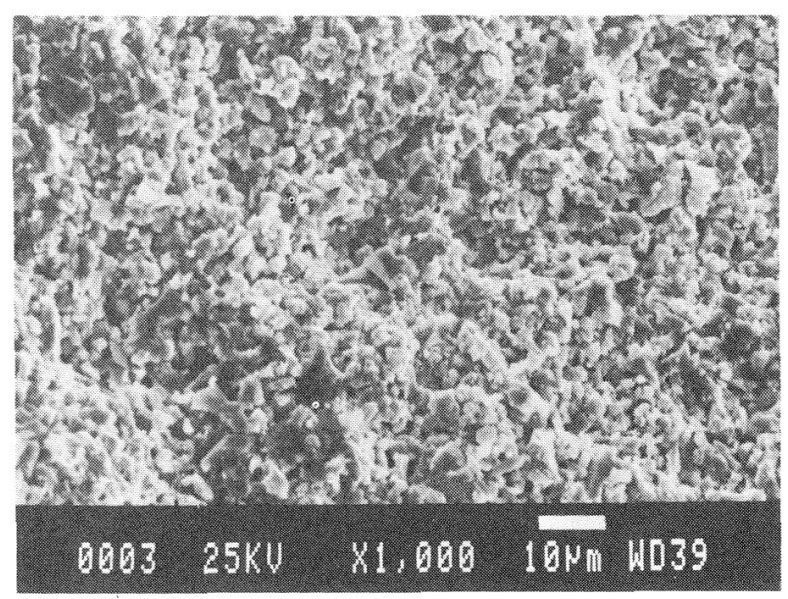

図９ＹＢＣＯホットプレス体の組織 


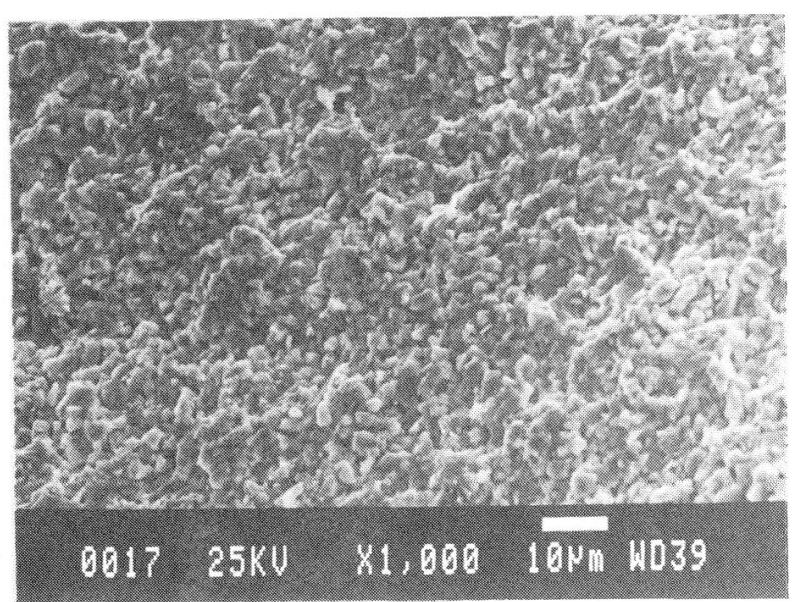

図10 $600^{\circ} \mathrm{C}$ て酸素アニールしたYBCO 焼結体

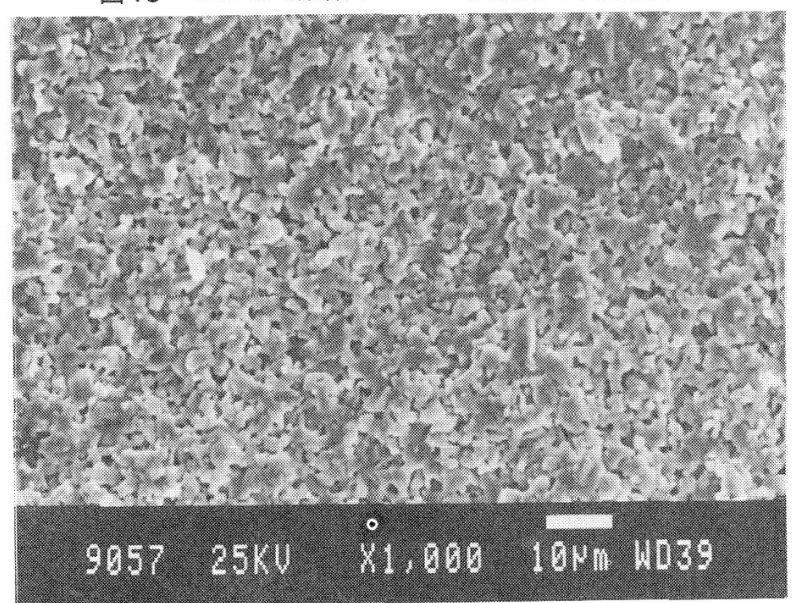

図11 $950{ }^{\circ} \mathrm{C}$ で酸素アニールした $\mathrm{YBCO}$ 焼結体

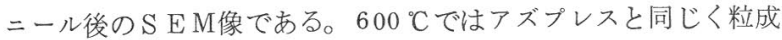

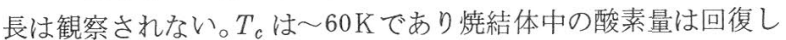
つつある。950ㄷ゙でニールすると $T_{0}=89 \mathrm{~K}$ であるが粓成長し，か なり脆い焼絬体となるが超電導特性はアズプレスの状態から回復 することが分かった。

BSCCO系では, 固相反応法により作製した $(1-1-1-2)$ 組 成で平均粒径〜 $4 \mu \mathrm{m}$ の原料粉末のホットプレス焼結を例として 用いよう。YBCO系と同様に原料粉を黒鉛モールドに充媜し，室 温より $200 \mathrm{~kg} / \mathrm{cm}^{2}$ の压力を保持したま ま780 ${ }^{\circ} \mathrm{C}$ まで昇温し 4 時間燒結する。 $700{ }^{\circ} \mathrm{C}$ 付近で墔密化が始まり, $750^{\circ} \mathrm{C}$ 以 上で著しく進行する。YBCO 系を異な り, 焼結体表面に著しい変質層は認め られない。図12にホットプレス焼結体 のX線回折図を示す。 $T_{c}=80 \mathrm{~K}$ 級の $(2-2-1-2)$ 相 $^{8)}$ が主となっている。 図13にホットプレス焼結体の破断面組 織を示す。焼結体密度は $5.1 \mathrm{~g} / \mathrm{cm}^{3}$ (理 論密度 $6.55 \mathrm{~g} / \mathrm{cm}^{3}$ ) とかなり緻密であ るが, Bi 系の特長である鱗片状の粒子 形状が見られる。構成粒子径は〜 $5 \mu \mathrm{m}$ と原料粉末と同程度で, 焼結中の粒成 長はかなり抑えられている。図14にホ ットプレス焼結体とプレス温度の関係 を示す。ホットプレス温度が $800{ }^{\circ} \mathrm{C}$ を こえると部分的な溶融現象のため成形

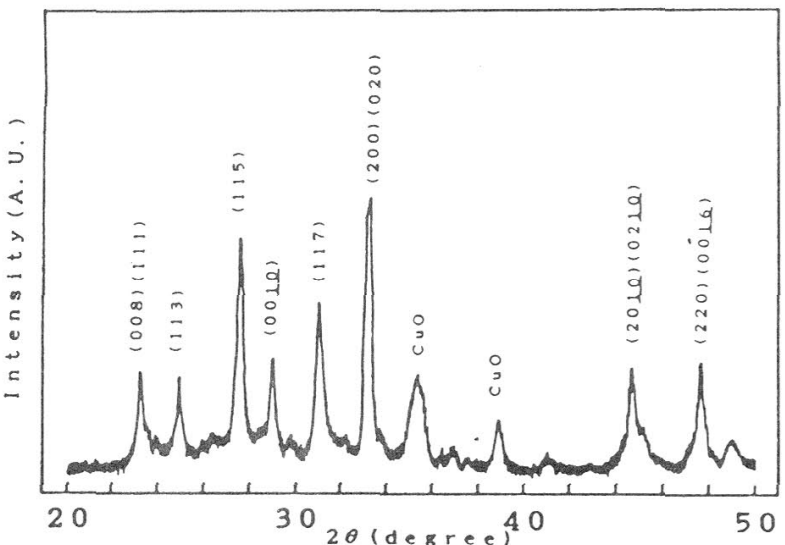

図12 Bi系ホットプレス体のX線回折パターン $(\mathrm{Cu}-\mathrm{K} \alpha)$

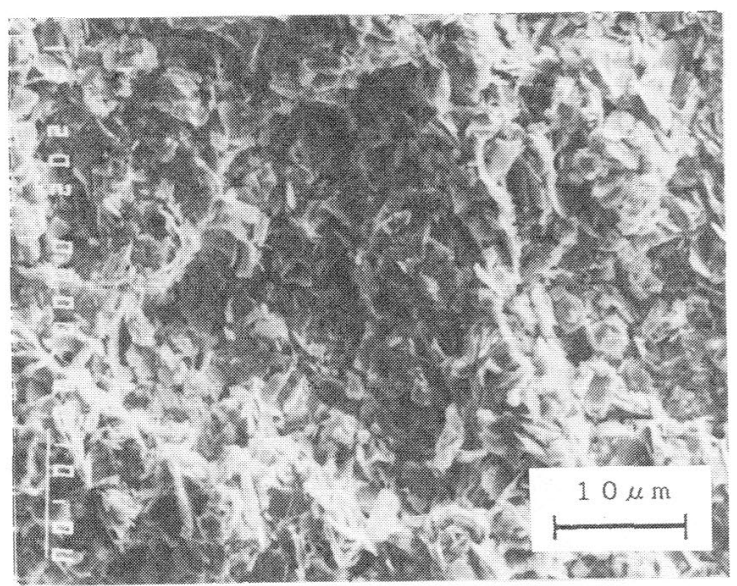

図13 Bi 系ホットプレス体の組織

不可能となる。溶融現象は原料粉組成が定比組成からずれている こととあいまって減圧条件下で加熱するため著しいようである。

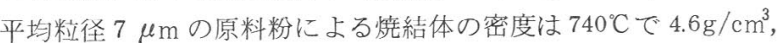
$780^{\circ} \mathrm{C}$ で $5.1 \mathrm{~g} / \mathrm{cm}^{3}$ となり多相系の焼結体であるが相対密度は〜 80 \%とかなり高密度の焼結体が容易に得られる。YBCO系, BSCCO 系ともに定比組成に過剩の $\mathrm{BaO}, \mathrm{CuO}, \mathrm{B} \mathrm{i}_{2} \mathrm{O}_{3}$ 等が加えられ焼結 されるが, $\mathrm{CuO}$ と $\mathrm{Bi}_{2} \mathrm{O}_{3}$ は焼結体密度の向上に役立っているよう である。図15はホットプレス焼結体密度の原料粉粒径依存性を示 したもので,ホットプレス条件は $T=780^{\circ} \mathrm{C}, P=200 \mathrm{~kg} / \mathrm{cm}^{2}$ であ

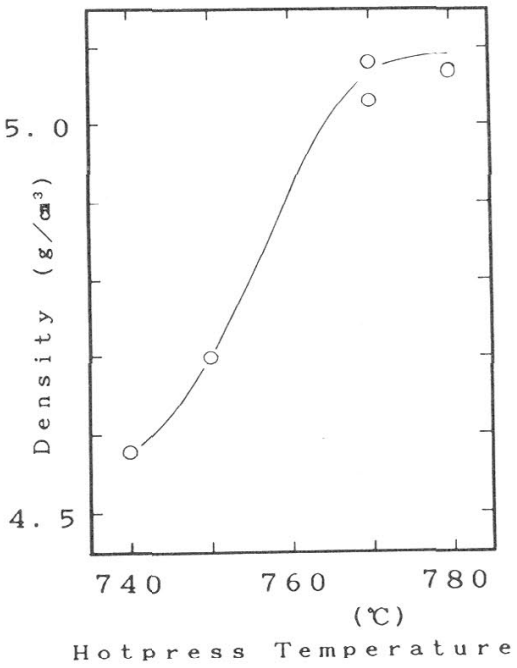

図14 Bi 系焼結体密度と燒結温度 (平均粒径 $7 \mu \mathrm{m}$ )

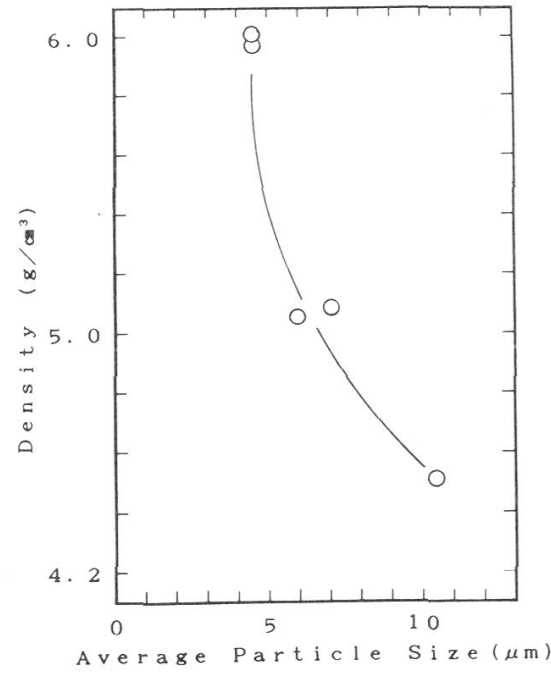

図15Bi 系焼結体密度と原料粉粒径 


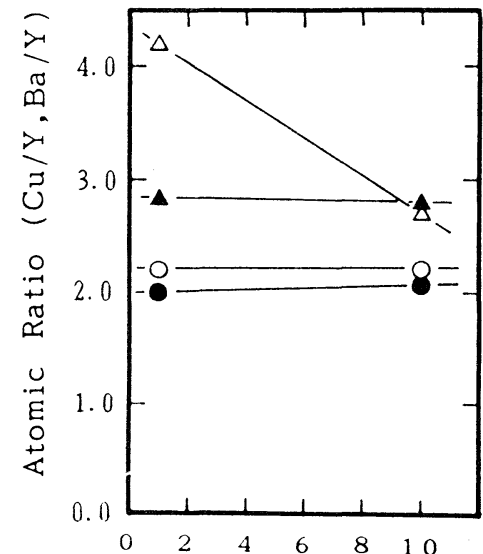

Total Pressure (mTorr)

$$
\left.\begin{array}{l}
-\triangle-\mathrm{Cu} / \mathrm{Y} \\
-\bigcirc-\mathrm{Ba} / \mathrm{Y} \\
-\mathbf{A}-\mathrm{Cu} / \mathrm{Y} \\
\mathbf{-}-\mathrm{Ba} / \mathrm{Y}
\end{array}\right\} \mathrm{Ar} / \mathrm{Ar}_{2}=1 / 1
$$

図16 YBCO系スパッタリング膜組成 （基板加熱なし）

る。粒径依存性は大きく, わずかの粉末粒径の差が焼結体密度に 大きく影響している。たとえば平均粒径 $10 \mu \mathrm{m}$ の原料粉では高々 $4.5 \mathrm{~g} / \mathrm{cm}^{3}$ であるが, 平均粒径 $4 \mu \mathrm{m}$ では $6.0 \mathrm{~g} / \mathrm{cm}^{3}$ の焼結体密度 となり, 相対密度 $90 \%$ 以上の高密度で均質なターゲット材を製造 するために原料粉粒径は重要なファクタであることが分かる。とく にBi 系の焼結においては, 原料粉が鱗片状の微粉末であるため粒 径とともに形状の効果が重要のようである。

\section{4. 薄膜製造への応用}

ホットプレス法で高密度焼結体を作製し, ターゲット材特性を ターゲット組成と付着膜組成の相関より評価した。

スパッタリング成膜法の原理は mTorr オーダの低圧雾囲気中 で 2 つの電極間 ( 基板とターゲット材 ) に高電圧を印加し, グロ 一放電を発生させ, 生じたイオンがターゲット材に衝突し, タ一 ゲッ卜構成物質を蒸発させ基板上に膜を付着させる成膜法である。 しかしグロー放電にともなう二次電子, 中性粒子等により基板が 照射されるためターゲット組成と付着膜組成に差が生じる9）10)。 この種の組成ずれは放電時のガス圧，放電電力，グロ一放電の形 状 (放電様式, 真空容器の大きさおよび形状等に依存) 等によっ て影響されるため, ニーザーの用いる装置によってターゲット組 成は変化し, 多様なものとなる。したがって, 各種の組成をもつ ターゲット材を容易に製造できることが製造法選択の 1 つの重要 な基準となっている。

図16，17は 5 インチターゲットを用い 2 極 $R F$ マグネトロンスパッ タリング装置での成膜試験の結果である。基板とターゲット間の 距離は70 mm で全圧 ( $1 \mathrm{mTorr}, 10 \mathrm{mTorr}$ ) と酸素分圧 (Arのみ, $\left.\mathrm{Ar} / \mathrm{O}_{2}=1 / 1\right)$ をパラメータとしている。基板は加熱していない。 膜中の元素組成はEPMAにより定量分析した。YBCO系では $\mathrm{Y}_{1.0} \mathrm{Ba}_{2.0} \mathrm{Cu}_{3.0} \mathrm{O}_{6.3}$ のターゲット組成で, $\mathrm{Ar}$ のみ全圧 $1 \mathrm{mTorr}$ の 条件下では $\mathrm{Y}_{1.0} \mathrm{Ba}_{2.2} \mathrm{Cu}_{4.4} \mathrm{O}_{\mathrm{x}}$ 組成の膜であるが酸素ガスを混合す ると $\mathrm{Y}_{1.0} \mathrm{Ba}_{2.0} \mathrm{Cu}_{2.8} \mathrm{O}_{\mathrm{x}}$ 組成の膜となり, 全圧を $10 \mathrm{mTorr}$ と変化さ せても膜組成はほとんど変化しない。本試験より $\mathrm{Cu}$ 含有量を少し

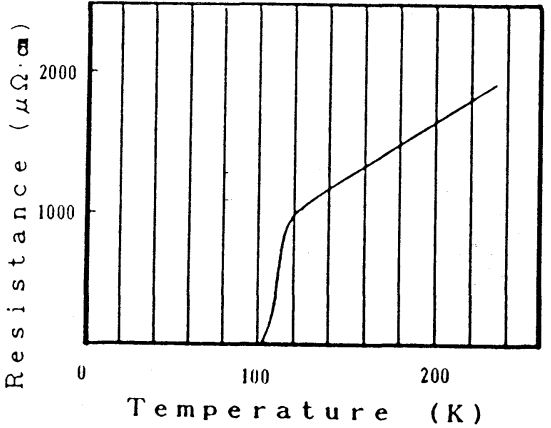

図18 Bi系薄膜の温度一電気抵抗特性

増した,たとえば( $1-2-3.4)$ 組成のター ゲット材を用いればYBCO系定比組成膜が 付着すると予想される。BSCCO 系もター ゲット組成 $(1-1-1-2)$ に比べて $\mathrm{Cu}$ 元素 の付着量が著しく少なくなっている。また Bi 元素もごく少量であるがSrに対して付着 量が减少している。 $T_{c}=107 \mathrm{~K}$ の超電導組成 $(2-2-2-3)$ 膜を作 製するためには, ターゲット材中の $\mathrm{Cu}$ と Biの含有量を増す必要が ある。図 18 は B i 系 (1-1-1-2) 組成ターゲットより全臣10 mTorr, $\mathrm{Ar} / \mathrm{O}_{2}=1 / 1$, の条件下でスパッタリング成膜後, 大気中, $860^{\circ} \mathrm{C}$ 100 時間アニールした膜の電気抵抗率の温度変化を示したもので, $T_{c}=101 \mathrm{~K}$ の超電導遷移が観測された。

\section{5.おおりに}

スパッタリング法により酸化物系超電導薄膜を作製する際，蒸 発源として用いられるターゲット材の製造法にうき, $\mathrm{YBCO}$ 系, BSCCO系を例として, 主として焼結用原料粉の合成法と焼結体 製造法につき, ターゲット材の品質に大きく影響する因子を取り あげ, 原料粉では粒径が重要な管理項目であること, 緻密で微細 な組織をもつ高純度ターゲット材の焼結にはホットプレス法が適 していることを述べた。

スパッタリング法による超電導薄膜の製造は, 今後とも成膜法 の主流であるが，付着膜組成をより精密にコントロールするため 多元ソースのスパッタリング法も大いに活用されると予想される ので, ターゲット材の種類もますます多様化するであろう。

$$
\text { 参考文 献 }
$$

1) Bednorz, J.G.\& Müller, K.A. : Z. Phys., B64, 189 $193,(1986)$

2) Wu, M.K., Ashbunn, J.R., Torng, C. J., Hor, P.H., Meng, R. L., Gao, L., Huang, Z.J., Wang, Y.Q.\& Chu, C.W. : Phys.Rev-Let t., 58, 908 910, (1987)

3) Maeda, H., Tanaka, Y., Fukutomi, Y.\& Asano, T. : Jpn. J. App1. Phys., 27, L209-210, (1988)

4) Sheng, Z. Z. \& Hermann, A. M. : Nature, 331, 55, (1988)

5）早川茂 ·和佐清孝 : 薄膜化技術, $13 \sim 41,(1982)$, 共立出版 (東京)

6）足立秀明 - 北香真 - 和佐清孝 : 固体物理, $23\left(\mathrm{~N}_{0} .8\right), 653 \sim 660$, (1988)

7）平林正之: 未踏加工技術, 212 ( 9 月号)，37〜48，(1987)

8) Endo,U., Koyama, S.\& Kawai, T, : Jpn. J.Appl. Phys., 27, L 1476 L 1479, (1988)

9）杉原忠・藤野修一. 大内幸弘・武下拓夫 : 第 35 回応用物理学関係 連合講演予稿集, $28 \mathrm{a}-\mathrm{W}-4$ (1988)

10）杉原忠・大内幸弘・藤野修一・武下拓夫 : 第 49 回応用物理学会学 術講演会講演予稿集, $7 \mathrm{P}$-館 $\mathrm{A}-10,(1988)$

\section{Development of Sputtering Targets of Oxide Superconductors for Thin Film Production}

1. Dr., Associate Manager 2. Researcher $\quad$ 3. Ph. D. Manager

$1 \sim 3$. Central Research Institute, Mitsubishi Metal Corporation 